\title{
Asymptomatic bacteriuria among pregnant women
}

\author{
Sudha Biradar Kerure ${ }^{1 *}$, Rajeshwari Surpur ${ }^{2}$, Sheela S. Sagarad ${ }^{3}$, Sneha Hegadi ${ }^{4}$
}

\author{
${ }^{1}$ Associate Professor in OB/GYN, Navodaya Medical College, Raichur, Karnataka, India \\ ${ }^{2}$ Associate Professor in Microbiology, Navodaya Medical College, Raichur, Karnataka, India \\ ${ }^{3}$ Senior Consultant in Obstetrics \& Gynecology, Raichur, Karnataka, India \\ ${ }^{4} \mathrm{PG}$ in Microbiology, Navodaya Medical College, Raichur, Karnataka, India
}

Received: 2 April 2013

Accepted: 14 April 2013

\section{*Correspondence:}

Dr. Sudha Biradar Kerure,

E-mail: dr_sudhabiradar@rediffmail.com

(C) 2013 Kerure SB et al. This is an open-access article distributed under the terms of the Creative Commons Attribution License, which permits unrestricted use, distribution, and reproduction in any medium, provided the original work is properly cited.

\begin{abstract}
Background: Urinary tract infections (UTIs) are the most common bacterial infections during pregnancy. Asymptomatic bacteriuria (ASB) is a major risk factor for the development of urinary tract infections during pregnancy and with further risk of preterm birth \& pyelonephritis if untreated.

Aims \& Objectives: This study was carried out to determine the prevalence of asymptomatic bacteriuria (ASB) in pregnant women \& to isolate, identify and establish antimicrobial susceptibility of pathogens.

Methods: A total of 500 pregnant women were studied over a period of one year. Clean catch midstream urine sample was collected into a sterile container \& then subjected to culture method.

Results: Significant bacteriuria was noted in 45 patients (9\%). 3\% patients had insignificant bacteriuria. Growth of contaminants was noted in $8 \% .80 \%$ samples were sterile with no growth. E. coli was the most common etiological agent, followed by Staphylococcus aureus.

Conclusions: Asymptomatic bacteriuria is not uncommon in antenatal patients. All pregnant women should be screened by urine culture to detect asymptomatic bacteriuria at their first visit to prevent overt UTI \& other complications in both mother \& fetus.
\end{abstract}

Keywords: Asymptomatic bacteriuria, UTI, Pregnant women, Urine culture

\section{INTRODUCTION}

Asymptomatic bacteriuria is common in women and increases in prevalence with age and/or sexual activity, due to short urethra, pregnancy, easy contamination of urinary tract with fecal flora. ${ }^{1-3}$ Asymptomatic bacteriuria (ASB) is defined as persistently \&actively multiplying bacteria in significant numbers i.e., $10^{5}$ bacteria per millilitre (ml) within the urinary tract without any obvious symptoms. ${ }^{4}$ The pregnant women are two times more commonly affected than age matched non pregnant females. ${ }^{5,6}$ This is due to urinary stasis due to progesterone effect in pregnancy in addition to different morphological \& physiological changes occurring during pregnancy.
Asymptomatic bacteriuria is found in $2-10 \%$ of pregnant women. ${ }^{3}$ Detection of ASB in antenatal women is important, as, undetected and untreated ASB may lead to symptomatic infection during that pregnancy in $25 \%$ of culture positive patients, acute pyelonephritis, hypertension in pregnant women, postpartum UTI, anaemia, preterm labour, low birth weight \& perinatal death of the fetus. ${ }^{2-4}$

Urine culture is the gold standard screening technique for ASB during pregnancy. ${ }^{7-9}$ The most common infecting organism is Escherichia Coli, which is responsible for 75$90 \%$ of bacteriuria during pregnancy. $25-30 \%$ of the asymptomatic bacteriuria cases develop into acute symptomatic UTI. Hence, early detection and treatment is 
of considerable importance not only to prevent acute pyelonephritis \& chronic renal failure in the mother, but also to reduce prematurity \& fetal mortality. ${ }^{1,7}$

\section{METHODS}

This prospective study was undertaken in 500 antenatal women, irrespective of their period of pregnancy, attending Obstetrics \& Gynecology OPD and those admitted in wards at Navodaya Medical College Hospital, Raichur, Karnataka over a period of one year from January 2012 to December 2012. Urine culture was performed in Microbiology laboratory. The study \& data collection were carried out with the approval from the Institutional Ethical Committee.

\section{Exclusion criteria:}

1) Symptoms suggestive of infections in urinary tract (dysuria, frequency \& urgency)

2) History of antibiotic therapy in previous two weeks

3) History of fever

4) Pregnancy induced hypertension

5) Pregnancy with Diabetes Mellitus; \&

6) Known congenital anomalies of urinary tract

Informed consent was taken \& antenatal women were counselled regarding the collection of "clean catch" mid stream urine sample in a sterile, wide mouthed container that can be covered with a tightly fitted lid. Microscopic examination of a wet film of uncentrifuged urine was carried out to detect the presence of the pus cells, erythrocytes, micro-organisms, casts etc. The urine samples were processed within 1-2hrs of collection, using standard microbiological procedures. The culture was done on 5\% sheep blood agar and Mac-Conkey agar by standard loop method and incubated at $37^{\circ} \mathrm{C}$ for 24 hours. Prolonged incubation was done for further $24 \mathrm{hrs}$ if no growth obtained. The identification of organisms was done by Gram staining, motility test, catalase test, oxidase test, coagulase test, and routine biochemical tests as per Cowan and Steels Manual. ${ }^{9}$ The growth was interpreted as sterile if no growth obtained. It was interpreted as Significant if the number of colonies corresponded to $10^{5}$ colony forming units (CFU) per ml. Insignificant growth was reported if colony count was less than $10^{5}$ CFUs per $\mathrm{ml}$.

The standardized Kirby-Bauer disc diffusion method on Muller Hinton agar plate as per recommendations of NCCLS (CLSI) was used for antibiotic sensitivity testing. ${ }^{10}$ The antibiotics tested were Ciprofloxacin, Norfloxacin, Erythromycin, Ampicillin, AmoxycillinClavulanic acid, Amikacin, Sparfloxacin, Cotrimoxazole, Cefotaxime, Ceftazidime, Nitrofurantoin, Piperacillin, Tazobactam, Imipenem, Tobramycin, Cefepime, and Cefoperazone-Sulbactam. All the asymptomatic bacteriuric pregnant women were advised to take treatment.

\section{RESULTS}

Out of 500 pregnant women examined for asymptomatic bacteriuria, 400 samples were sterile with no growth. Significant bacteriuria was found in $45(9 \%)$ cases and insignificant bacteriuria in $15(3 \%)$ cases. Growth of contaminants was seen in 40(8\%) samples (Table 1).

Table 1: Results of culture.

\begin{tabular}{|lll|}
\hline Results of culture & No. of cases & $\%$ \\
\hline Significant bacteriuria & 45 & 9 \\
\hline Insignificant bacteriuria & 15 & 3 \\
\hline Contamination & 40 & 8 \\
\hline Sterile & 400 & 80 \\
\hline Total & 500 & 100 \\
\hline
\end{tabular}

Table 2: Age distribution of culture positive cases.

\begin{tabular}{|lll|}
\hline Age (years) & $\begin{array}{l}\text { No of culture } \\
\text { Positive cases }\end{array}$ & $\%$ \\
\hline $18-25$ & 13 & 28 \\
\hline $26-35$ & 23 & 52 \\
\hline$>36$ & 09 & 20 \\
\hline Total & 45 & 100 \\
\hline
\end{tabular}

The highest number of culture positive cases among pregnant women were in the age group of 26-35 years (52\%), followed next by $18-25$ years $(28 \%) \&>36 y e a r s$ (20\%). The youngest among the cases studied was 18 years old \& the oldest was 39 years old (Table 2 ).

Significant bacteriuria was found more in primigravida $(56 \%)$ than multigravida (44\%).

In our study, maximum number of culture positive cases were noted in second trimester $(44.4 \%)$, followed next by first trimester $(28.8 \%)$ and third trimester $(26.6 \%)$ (Table 3).

Table 3: Trimester wise distribution of culture positive cases.

\begin{tabular}{|c|c|c|}
\hline Trimester & $\begin{array}{l}\text { No. of culture } \\
\text { positive cases }\end{array}$ & $\%$ \\
\hline First & 13 & 28.8 \\
\hline Second & 20 & 44.4 \\
\hline Third & 12 & 26.6 \\
\hline Total & 45 & 100 \\
\hline
\end{tabular}

The commonest isolated organism was E. coli in 35 patients $(77.77 \%)$, followed by S. aureus in 5 patients (11.11\%), Klebsiella pneumonia in 3 cases $(6.66 \%)$, Acinetobacter \& Citrobacter each in one case $(2.22 \%)$ of culture positive cases (Table 4).

In our study, three organisms $(6.66 \%)$ were found to be resistant to first line antimicrobial drugs like Ampicillin, Co-trimoxazole, Norfloxacin, Cefoperazone \& 
Nitrofurantoin. Out of three isolates, one each were E. coli, K. pneumoniae \& S. aureus. The three isolates were found to be sensitive to second line drugs. K. pneumoniae was sensitive to Amikacin, E. coli was sensitive to Cefuroxime \& Ceftazidime, and S. aureus was sensitive to Amoxicillin-Clavulanic acid.

Table 4: Distribution of culture positive cases according to bacterial isolates.

\begin{tabular}{|lll|}
\hline Name of Isolate & No. of cases & $\%$ \\
\hline E. coli & 35 & 77.77 \\
\hline S. aureus & 05 & 11.11 \\
\hline Klebsiella pneumonia & 03 & 6.66 \\
\hline Citrobacter & 01 & 2.22 \\
\hline Acinetobacter & 01 & 2.22 \\
\hline Total & 45 & 100 \\
\hline
\end{tabular}

\section{DISCUSSION}

Urinary tract infections are common in females \& that too in pregnancy. Asymptomatic bacteriuria of pregnancy needs special attention, due to lack of symptoms \& its adverse consequences in pregnancy. A cost evaluation study reported that screening for pyelonephritis is appropriate when the prevalence of ASB is greater than $2 \%{ }^{11}$ In our study, we found the prevalence of ASB to be $9 \%$ and so, screening all antenatal women for ASB, especially in early pregnancy by a quantitative urine culture is recommended.

Overall, the incidence in various Indian studies was found to be between $5 \& 12 \%$, and in Western studies, the incidence ranges from $2-7 \% .^{12}$ In the present study, significant bacteriuria was found in $9 \%$ cases, which was almost similar to other studies. ${ }^{3,7,13}$ This may be due to stasis produced by gravid uterus, and since most E. coli strains prefer that environment, they cause UTI. Another reason could be as a result of poor genital hygiene practices by pregnant women who may find it difficult to clean their anus properly after defecating or clean their genitals after passing urine. ${ }^{1,13}$

Antenatal women in age group 26-35 years had highest percentage of culture positive cases $(52 \%)$, followed by $18-25$ years age $(28 \%) \&>36$ years age $(20 \%)$ respectively (Table 2). Similar age pattern was also observed in other studies. ${ }^{13-15}$ The reason may be due to that, women between 26-35 years age group may be multiparous, and multiparity is a risk factor for acquiring asymptomatic bacteriuria in pregnancy. ${ }^{13,16,17}$

In our study, most culture positive cases were seen in second trimester $(44.4 \%)$, which was similar to Girishbabu R J study ${ }^{1}$ and Nath et al study ${ }^{5}$.

The gram negative bacteria were mainly responsible for asymptomatic bacteriuria. E. coli was commonly found in 35 cases $(77.77 \%)$ in our study which is similar to different studies, where also E. coli was found to be the commonest isolate. . $^{6-20}$

The isolates were most sensitive to nitrofurantoin and imipenem, followed by ceftazidime, amikacin, cefotaxime, co-trimoxazole, amoxicillin-clavulanic acid $\&$ erythromycin.

Incidence of low birth weight babies (50\%) and prematurity $(75 \%)$ was higher in untreated asymptomatic bacteriuric patients in a study by Lavanya $\mathrm{S} \mathrm{V}$ et $\mathrm{al}^{18}$ and Nath et $\mathrm{al}^{5}$.

P. Mitra et $\mathrm{al}^{21}$ found pre-eclamptic toxemia was more common in the bacteriuric group $(9.1 \%)$ as compared to abacteriuric group (6\%).

All patients with significant bacteriuria were advised to take appropriate antibiotics as per the sensitivity report.

\section{CONCLUSION}

Significant bacteriuria was present in $9 \%$ in this study. The most sensitive test for its detection is urine culture with clean-catch mid stream urine. Women with ASB may have serious consequences on both mother \& child. Therefore, it is important to screen all antenatal women for asymptomatic bacteriuria at their first prenatal visit, preferably in first trimester, and those who are positive should be followed up closely after treatment because about $1 / 3^{\text {rd }}$ will experience a recurrence.

\section{ACKNOWLEDGEMENTS}

We sincerely thank our honourable Chairman, Medical Director, Principal and all the staff of Navodaya Medical College, Raichur, Karnataka, India for their constant support and for providing facilities to conduct this study.

Funding: No funding sources

Competing interests: There are no competing interests to declare

Ethical approval: The study was approved by the institutional ethical committee

\section{REFERENCES}

1. Girishbabu RJ, Srikrishna R, Ramesh ST. Asymptomatic bacteriuria in pregnancy. Int $\mathrm{J}$ Biol Med Res 2011;2:740-2.

2. Anantnarayana R, Paniker J. Ananthanarayana and Paniker's text book of Microbiology. $7^{\text {th }} \mathrm{Ed}$; 2005:275.

3. Enayat K, Fariba F, Bahram N. Asymptomatic bacteriuria among pregnant women referred to out patient clinics in Sanandaj, Iran. Int Braz J Urol 2008;34:699-707.

4. Cunningham FG, Gant NF, Laveno KJ, et al. Renal and urinary tract disorders. Williams Obstetrics. 
21st Ed. New York: McGraw-Hill Medical Publishing Division; 2001:1253-4.

5. Nath G, Chaudhary M, Prakash J, et al. Urinary tract infection during pregnancy and fetal outcome. Indian J Med Microbiol 1996;14:158-60.

6. Chandel LR, Kanga A, Thakur K, et al. Prevalence of Pregnancy Associated Bacteriuria: A study done in a tertiary care Hospital. J Obstet Gynecol India 2012;62:511-4.

7. Gayathree I, Shetty S, Deshpande SR, Venkatesh DT. Screening for asymptomatic bacteriuria in pregnancy. An evaluation of various screening tests in Hassan District Hospital, India. JCDR 2010;4:2702-6.

8. Patterson TF, Andriole VT. Bacteriuria in pregnancy. Infect Dis Clin North Am 1987;1:80722.

9. Cowan and Steels manual for the identification of medical bacteria. In: Barrow GI, Feltham RKA, editors. 3rd ed. Cambridge: Cambridge University Press; 1993.

10. Clinical and Laboratory Standards Institute. Performance standards for antimicrobial susceptibility testing: 17th informational supplement. CLSI / NCCLS document M100-S17. Clinical and laboratory Standards Institute, Wayne, Pennsylvania; 2007:27(1).

11. Rouse DJ, Andrews WW, Goldenberg RL, Owen J. Screening and treatment of asymptomatic bacteriuria of pregnancy to prevent pyelonephritis : a cost-effectiveness and cost-beneficial analysis. Obstet Gynecol 1995;86:119-23.

12. Yashodhara P, Mathur R, Raman I. Urinary tract infection in pregnancy. Indian $\mathrm{J}$ Med Res 1987;86:309-14.

13. Imade PE, Izekor PE, Eghafona NO, Enabuele OI, Ophori E. Asymptomatic bacteriuria among pregnant women. North Am J Med Sci 2010;2:2636.
14. Turpin CA, Minakh B, Danso KA, Frimpong EH. Asymptomatic bacteriuria in pregnant women attending antenatal clinic at Komfo Anokye Teaching hospital, Kumasi, Ghana Med J 2007;41:26-9.

15. Amadi ES, Enemuo OB, Uneke CJ, Nwosu OK, et al. Asymptomatic bacteriuria among pregnant women in Abakahki, Ebonyi State. Nigeria J Med Sci 2007;7:698-700.

16. Akinloye O, Ogbolu DO, Akinloye OM, Terry Alli OA. Asymptomatic bacteriuria of pregnancy in Ibadan, Nigeria: a re-assessment. Br J Biomed Sci 2006;63:109-12.

17. Fatima N, Ishrat S. Frequency and risk factors of asymptomatic bacteriuria during pregnancy. J Coll Physicians Surg Pak 2006;16:273-5.

18. Lavanya SV, Jogalokshmi D. Asymptomatic bacteriuria in antenatal women. Int $\mathrm{J}$ Med Microbiol 2002;20:105-6.

19. Kriplani A, Buksheek K, Ratan A. Asymptomatic bacteriuria in pregnant Indian patients at All India Institute of Medical Sciences, New Delhi and treatment with single dose antimicrobial therapy. J Obstet Gynecol India.1993;43:489-91.

20. Mac Nair RD, MacDonald SR, Dooley SL, et al. Evaluation of the centrifuged and gram- stained smear urinalysis and reagent strip testing to detect asymptomatic bacteriuria in Obstetric patients. Am J Obstet Gynecol 2000;182:1076-9.

21. Mitra P, Kulkarni VA, Sengupta SR, et al. Urinary tract infection in pregnancy. J Obstet Gynecol India. 1977;27:711-8.

DOI: $10.5455 / 2320-1770 . \mathrm{ijrcog} 20130621$

Cite this article as: Kerure SB, Surpur R, Sagarad SS, Hegadi S. Asymptomatic bacteriuria among pregnant women. Int J Reprod Contracept Obstet Gynecol 2013;2:213-6. 